\title{
Potential of East African phosphate rock deposits in integrated nutrient management strategies
}

\author{
BASHIR JAMA ${ }^{1}$ and PETER VAN STRAATEN ${ }^{2}$ \\ ${ }^{1}$ World Agroforestry Centre (ICRAF), PO Box 30677, Nairobi, Kenya \\ ${ }^{2}$ Department of Land Resource Science, University of Guelph, Guelph, ON, Canada N1G 2W1 \\ Manuscript received on September 29, 2005; accepted for publication on March 13, 2006; \\ presented by OTHON H. LEONARDOS
}

\begin{abstract}
Phosphorus deficiency affects around $80 \%$ of the acid soils of western Kenya, but fertilizer use is limited due to high prices. This paper explores the potential of local phosphate rocks (PR) as a remedy within the context on an integrated soil fertility management approach. A promising phosphate rock is Minjingu PR (MPR, Tanzania), a sedimentary/biogenic deposit which contains about $13 \%$ total $\mathrm{P}$ and 3\% neutral ammonium citrate (NAC) soluble P. On-farm trials in P-deficient soils in western Kenya demonstrate MPR to be as effective as triple superphosphate (TSP, $20 \% \mathrm{P}$ ) at equal P rates. The benefits are most pronounced with the integration of agroforestry technologies that improve soil fertility. Besides Minjingu PR, Busumbu PR from Uganda (BPR) is potentially another source of P. It is typical of the abundant but unreactive igneous PRs in eastern, central and southern Africa. Agronomic performance of BPR is poorer, though its lower cost and location near to P-deficient areas in western Kenya make it attractive in some situations. The policy implications of these findings are discussed further in the paper.
\end{abstract}

Key words: fertilizers, maize, improved fallows, Tithonia, East Africa.

\section{INTRODUCTION}

Soil fertility depletion in smallholder farms is the major biophysical root cause for the declining per-capita food production in most of sub-Saharan Africa (Sanchez et al. 1997). This is attributed to inputs of nutrients not exceeding losses, especially with harvested products. One such area is western Kenya, where phosphorus losses of 3-13 $\mathrm{kg} \mathrm{ha}^{-1}$ $\mathrm{yr}^{-1}$ over several decades have led to maize yields of $<1.0 \mathrm{t} \mathrm{ha}^{-1}$ (Sanchez et al. 1997). Meanwhile, population growth coupled with reduction in farm sizes has resulted in less land available for food production. This situation poses a serious threat

Correspondence to: Peter van Straaten

E-mail: pvanstra@uoguelph.ca to food security throughout eastern and southern Africa.

Although P deficiency is widespread in East Africa, it is most severe in the densely populated highlands of western Kenya. Responses of maize to $\mathrm{P}$ are significant even at rates as low as $10 \mathrm{~kg}$ $\mathrm{P} \mathrm{ha}^{-1}$ (Jama et al. 1997) indicating the importance of adding $\mathrm{P}$ to crops in this area with good rainfall (1600 to $1800 \mathrm{~mm}$ ). Several studies indicate that about $80 \%$ of the smallholder land used for maize production is deficient in available soil $\mathrm{P}$. Once $\mathrm{P}$ deficiency is overcome through $\mathrm{P}$ inputs, $\mathrm{N}$ limits maize growth in nearly all cases. After $\mathrm{P}$ and $\mathrm{N}$ deficiencies are overcome, $\mathrm{K}$ limits maize growth in about $25 \%$ of the area. 
Options for $\mathrm{P}$ inputs are organic materials, mineral $\mathrm{P}$ fertilizers or phosphate rocks (PR). Manure is the most common organic fertilizer in western Kenya, but the majority of farmers in the area owns no livestock and therefore has no source of manure (Shepherd and Soule 1998). Phosphorus content of organic materials (e.g. leaves of trees and shrubs, farmyard manure) are generally low and do not provide enough $\mathrm{P}$ for annual crops (Palm et al. 1997). Soluble $P$ fertilizers remain prohibitively expensive for most smallholder farmers, for instance, over 500 US dollars per tonne compared to 120-150 US dollars in the global markets. So attention has focused on regionally available phosphate rocks (PRs).

There are PR deposits in East Africa, which have a proven capacity to alleviate phosphorus deficiency. The prevailing soil conditions are also attractive to the use of PR. The direct use of PR generally requires $\mathrm{P}$-deficient acidic soils with $\mathrm{pH}$ less than 5.5 (Sanchez 1976, Rajan et al. 1996). This is the case for most soils in western Kenya. The soils, mostly Eutrudox and Kandiudalfs, also accumulate considerable amounts of nitrate nitrogen at depth (0.5 to $2.0 \mathrm{~m}$ ) (Hartemink et al. 1996) and the utilization of this $\mathrm{N}$ through cropping systems involving woody perennials can enhance the use efficiency and economic benefits of the $\mathrm{P}$ applied.

This paper highlights the potential use of PR as source of $\mathrm{P}$ for crops in P-deficient soils in East Africa. Also highlighted, using research results from western Kenya, are the benefits derived from integrating P sources with organic sources of nutrients in soils with multiple nutrient deficiencies.

\section{PHOSPHATE TYPES AND ROCK USE}

The use of indigenous PR has recently received tremendous interest as an alternative to mineral $\mathrm{P}$ fertilizers that are nearly all imported, highly priced and often unavailable to smallholder farmers when needed. Some benefits of PR over mineral fertilizers in the region include: a) cheaper source of $P$ for crops and, therefore, saves scarce foreign exchange earnings for countries of the region,

b) become an export commodity to nearby countries, thereby strengthening national economies and regional trade linkages and;

c) generate employment opportunities.

There are a number of PR deposits of variable reactivity in East Africa (van Kauwenbergh 1991, van Straaten 2002). They, however, differ greatly in their $\mathrm{P}$ composition and suitability as sources of $\mathrm{P}$ for P-deficient soils such as those in western Kenya. According to van Straaten (2002), the most promising PR sources are Minjingu in northern Tanzania and Busumbu and Sukulu in eastern Uganda.

A number of studies have highlighted the suitability of Minjingu PR as P source for crops in P-deficient soils (Buresh et al. 1997). For example, Bromfield et al. (1981) reported a relative agronomic effectiveness (RAE) of $75 \%$ for Minjingu PR in the five seasons following application to maize in western Kenya. Relative agronomic effectiveness is defined as yield increase with PR relative to that with TSP expressed as a percentage. For correct determination of RAE, P should be the only nutrient limiting crop yield. Based on results of 559 comparisons of rock and fertilizer at equal levels of added P, Woomer et al. (1997) observed higher maize yield increases with Minjingu PR than with some other PRs found in Africa. They concluded that strong potentials exist to further develop the Minjingu PR and that the immediate target should be western Kenya, where farmers cultivate highly weathered, P-deficient soils.

Minjingu PR is a biogenic type sedimentary deposit (van Straaten 2002), which is believed to have been formed when Lake Manyara was an extensive alkaline lake and the current Minjingu Hill was an island. The deposit is thought to have resulted from the deaths of the large numbers of cormorants (Phalacrocorax kuehnensis) that used to roost on the island. The Minjingu deposit was dis- 
covered in 1956 but PR production commenced only in 1983. There are two types of the Minjingu PR: 'soft' phosphate ore estimated to be 3.3 million tonnes and 'hard' ore of about 4.8 million tonnes. An unpublished report by the International Fertilizer Development Center (IFDC, unpublished data), however, indicates lower reserve figures of close 0.6 million tonnes exploitable soft phosphate ore and higher figures of 10 million tonnes for the hard phosphate ore. Current and previous production has concentrated on the soft ore. The soft ore is processed by dry beneficiation, by crushing, screening and bagging of the dried product. The concentrated final product contains about $12.5 \% \mathrm{P}$, with a neutral ammonium citric (NAC) solubility of about $5.6 \%$. Presently, limited operations are going on at the mine. The mine and beneficiation plant has been privatized and there is a sales outlet in Nairobi/ Kenya of Minjingu PR that can supply large or small orders from the Minjingu Phosphate Company (Paul Mwaluko, personal communication, June 2005).

With the exception of the Minjingu PR deposit, most of the other PR deposits of eastern and southern Africa are weathered carbonatite deposits of igneous origin and of generally low solubility, and often with substantial $\mathrm{Fe}$ and $\mathrm{Al}$ oxide contents. Typical of such deposits is Busumbu PR in eastern Uganda. The Busumbu phosphate deposit occurs in a large, 26 million year old alkaline ring complex (Davies 1947, Baldock 1969, E. Katto, unpublished data). This deposit, 2,000 $\mathrm{m}$ long and $400 \mathrm{~m}$ wide, is made up of a deeply weathered carbonatite. Two types of PR are found at Busumbu: hard rock, 12-13.3\% $\mathrm{P}$, and soft rock, 7.9-9.9\% $\mathrm{P}$. The soft rock constitutes nearly $90 \%$ of the estimated total deposit of about 8.5 million tonnes of ore (E. Katto, unpublished data, van Straaten 2002). The soft ore contains impurities, particularly magnetite, which can be removed with relatively simple techniques to produce a concentrate containing $13 \% \mathrm{P}$. The original composition of the carbonatite consists of a calcite-magnetite phlogopite apatite assemblage.
The Busumbu deposit was mined between 1945 and 1963 for direct application PR and to supply raw materials for P-fertilizer production in Kenya. The NAC solubility of the Busumbu PR as reported by van Kauwenberg (1991) is with $2.3 \%$ relatively low.

Phosphate rocks with low reactivity can be processed in different ways to improve RAE. One such method is blending with soluble $\mathrm{P}$ fertilizer such as triple superphosphate (TSP) or monoammonium phosphate (MAP) to increase its reactivity. The method of blending and compaction with PR with water-soluble $\mathrm{P}$ fertilizer, such as TSP has been described and tested by Chien et al. (1987, 1996) and van Straaten and Fernandes (1995). One of the problems encountered with the Busumbu soft ore is the high amount of Fe-oxides. But large amounts of Fe-oxide impurities, particularly magnetite, can be removed through magnetic separation using inexpensive small-scale operations. This simple processing results in a Busumbu PR concentrate of $13 \% \mathrm{P}$ which can then be blended with mineral fertilizers (e.g. TSP) to increase its reactivity. Through the hydrolysis of TSP, the blend provides an initial quick dose of $\mathrm{P}$ and a sustained slow release of $\mathrm{P}$ as the acid produced by the hydrolysis process slowly reacts with the PR (van Straaten and Fernandes1995, van Straaten 2002). The technology of compaction and pelletization has low capital and energy requirements and can be carried out in module units of various scales. Busumbu PR concentrate and a blend made from it have been tested with mixed results in researchermanaged field trials in western Kenya (Smithson et al. 2003, S.O. Ngoze, unpublished data). From experiments carried out by Chien et al. (1996) it was speculated that the small amount of water soluble $\mathrm{P}$ in the blend (from the TSP) acts as starter dose that will stimulate early root growth.

Busumbu PR is of lesser reactivity than Minjingu PR but the close proximity to western Kenya ( $<$ than $20 \mathrm{~km}$ away) compared with Minjingu (>820 km away) makes it attractive. There are other known natural PR deposits in East Africa 
(van Straaten 2002) but they are not as reactive as either Minjingu PR, and none of them is currently mined.

\section{PHOSPHATE ROCK STUDIES IN WESTERN KENYA}

ICRAF, in collaboration with Kenya Agricultural Research Institute (KARI), Kenya Forestry Research Institute (KEFRI) and Tropical Soil Biology and Fertility (TSBF) Programme of CIAT, began work with Minjingu PR in western Kenya in 1996. Maize (Zea mays) was used as test crop. Maize is the staple food crop of the people in this area. However, its low yield is not sufficient to feed the large number of people in the area, with households typically consisting of 5-7 people (Swinkels et al. 1997). As a consequence, there has been considerable migration of people to cities and farms elsewhere to seek off-farm employment that can supplement their food and other needs.

The first nutrient replenishment study compared Minjingu PR with TSP at annual applications of $50 \mathrm{~kg} \mathrm{P} \mathrm{ha}^{-1}$ and a large one-time application of $250 \mathrm{~kg} \mathrm{P} \mathrm{ha}{ }^{-1}$. The two $\mathrm{P}$ rates represent two different strategies of phosphorus application - a large one-time application $\left(250 \mathrm{~kg} \mathrm{P} \mathrm{ha}^{-1}\right)$ that is expected to provide a strong residual effect for at least five years, and annual applications of $50 \mathrm{~kg} \mathrm{P} \mathrm{ha}^{-1}$ applied to the rainy season maize crop. Potassium was blanket applied to all treatments at $60 \mathrm{~kg} \mathrm{ha}^{-1}$. Nitrogen was applied annually at the recommended rate of $60 \mathrm{~kg} \mathrm{ha}^{-1}$ for maize in the area through either urea or foliar biomass of Tithonia diversifolia, a shrub common in hedges and roadsides in western Kenya. The $\mathrm{N}$ rate of $60 \mathrm{~kg} \mathrm{ha}^{-1}$ is the recommended rate for maize in area. Maize yield responses to $\mathrm{N}$ application beyond this rate are usually small, probably because of the inherently high organic matter (3.0 to $3.3 \%$ ) of the soils in many areas. Rapid mineralization of soil organic matter under the humid and hot conditions of the area can often supply $\mathrm{N}$ sufficient for at least $1.0 \mathrm{t}$ dry matter $\mathrm{ha}^{-1}$ maize grain yield.

Tithonia foliage has high concentrations of N,
$\mathrm{P}$ and $\mathrm{K}$ and decomposes very rapidly in the soil (Jama et al. 2000). A soil fertility enhancement study was conducted for 10 seasons at three sites, where the soils are classified as Kandiudalfic Eutrudox (Soil Taxonomy) or Ferralsol (FAO-UNESCO), with a $\mathrm{pH}$ of 5.1 with clay content of 30 to $35 \%$ in the topsoil (0-15 cm layer). These sites are fairly representative of the soils and rainfall conditions of the western Kenya highlands neighboring Lake Victoria.

The annual maize yield from the five maize cropping seasons (long-rains season) in the five years, averaged over three sites, indicated comparable response for the two $\mathrm{P}$ sources, i.e. TSP and Minjingu PR. Maize yield increased dramatically with the application of $\mathrm{P}$ at either 50 or $250 \mathrm{~kg} \mathrm{ha}^{-1}$ (Fig. 1). It is interesting to note the comparable yields of the MPR and TSP P sources and rates, and higher than the no-P situation by 3-4 $\mathrm{t} \mathrm{ha}^{-1}$. Without $\mathrm{P}$ but urea as $\mathrm{N}$ source, maize grain yield averaged only $1.0 \mathrm{t} \mathrm{ha}^{-1}$. Such low maize grain yields are typical in this area, which has highly P deficient soils (Sanchez et al. 1997).

The RAE of Minjingu PR from this study averaged $83 \%$ with Tithonia and $96 \%$ with urea as $\mathrm{N}$ source. In another multi-location study, RAE of Minjingu PR averaged only $70 \%$ in the first year in $26 \mathrm{P}$ responsive sites in western Kenya (M. Lijzenga, unpublished data). In a long-term trial with maize on an acid, P-deficient soil in western Kenya, the RAE in the first season after $\mathrm{P}$ application averaged $74 \%$ at $50 \mathrm{~kg} \mathrm{Pha}^{-1}$ and $80 \%$ at $250 \mathrm{~kg} \mathrm{P} \mathrm{ha}{ }^{-1}$ (ICRAF 1998). These high RAEs suggest that Minjingu PR could be used as a substitute for TSP.

Also notable from Fig. 1 is the increase of yield from 1.0 to $2.1 \mathrm{t} \mathrm{ha}^{-1}$ with Tithonia alone as compared with urea with no $\mathrm{P}$ addition. Doubling or tripling of maize yields with Tithonia biomass applied at about $2 \mathrm{t}$ dry matter ha- ${ }^{-1}$ without mineral fertilizers have been recorded in many trials conducted on-farm in western Kenya (Nyasimi et al. 1997). Tithonia adds some $\mathrm{P}$ to the soil (about 6-7 $\mathrm{kg} \mathrm{ha}^{-1}$ with $2 \mathrm{t}$ dry matter ha ${ }^{-1}$ Tithonia leaf 


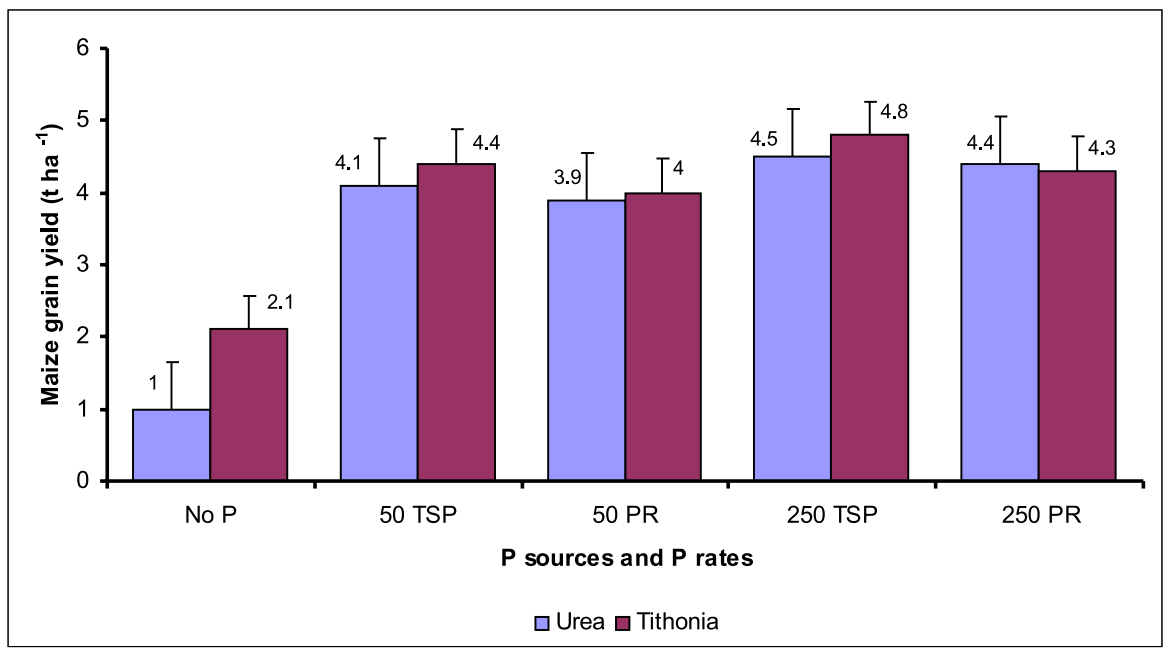

Fig. 1 - Maize responses to phosphorus and Tithonia applications in western Kenya. Average of 3 on-farm experiments summed over 5 cropping seasons ('long rains'). The green foliar biomass of Tithonia diversifolia was incorporated into the soil at the beginning of the long-rains at the rate of $1.8 \mathrm{t}$ dry matter ha ${ }^{-1}$ to provide $60 \mathrm{~kg} \mathrm{~N} \mathrm{ha}^{-1}, 6 \mathrm{~kg} \mathrm{Pha}^{-1}$ and $60 \mathrm{~kg} \mathrm{~K} \mathrm{ha}^{-1}$. Triple superphosphate (TSP) and Minjingu phosphate rock (PR) were added at a recapitalization rate of $250 \mathrm{~kg} \mathrm{Pha}^{-1}$ (250) or annually at $50 \mathrm{~kg} \mathrm{Pha}^{-1}$ (50). Blanket potassium application of $60 \mathrm{~kg} \mathrm{~K} / \mathrm{ha}$ was added to each crop. Source: Bashir Jama (unpublished data).

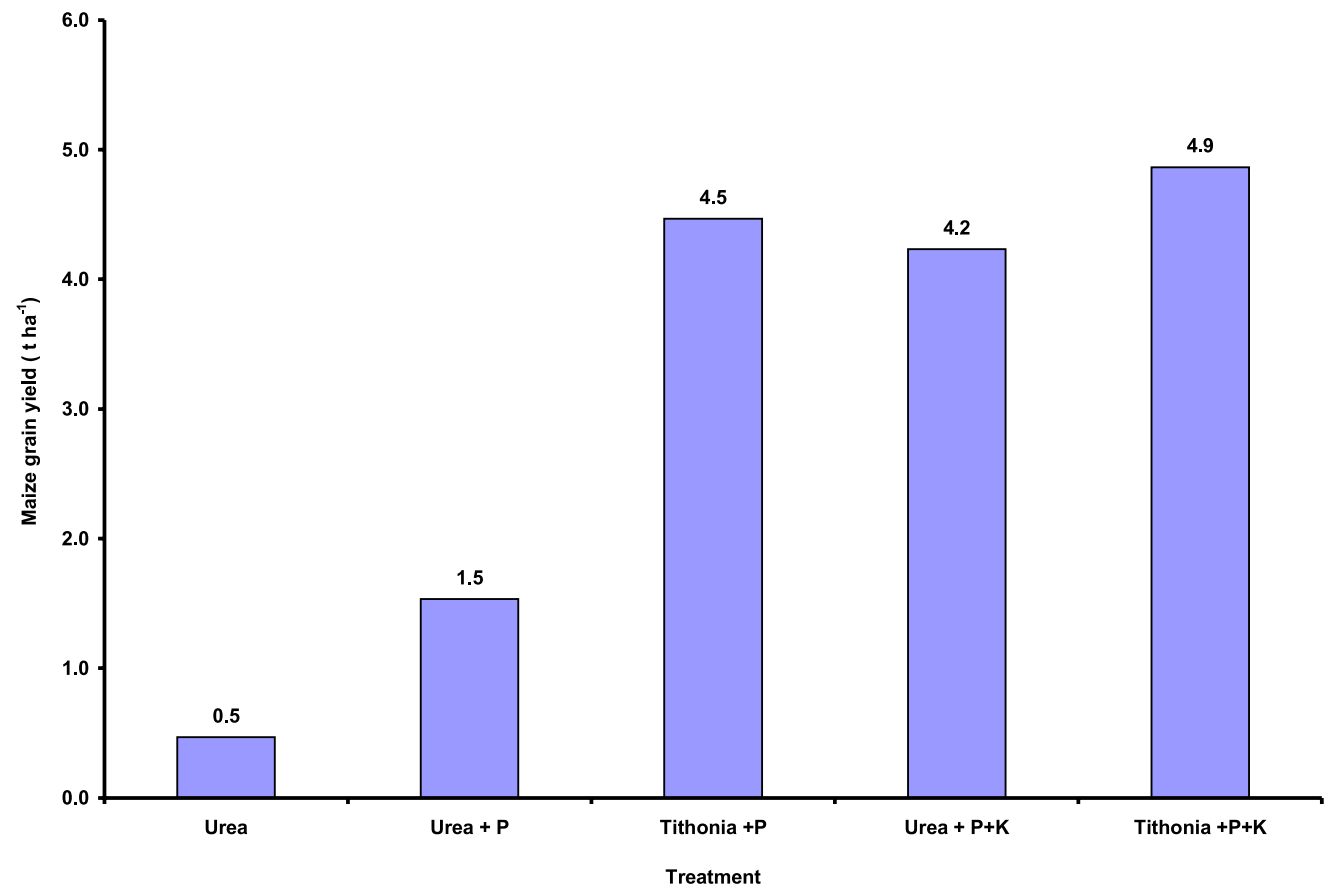

Fig. 2 - Effect of Tithonia green foliage as a source of $\mathrm{N}$ and $\mathrm{K}$ for maize compared with inorganic fertilizer when $\mathrm{P}$ is supplied to both at N, P and K deficient soil on six seasons average maize grain yield. Nitrogen and Potassium were applied at the rate of $60 \mathrm{~kg}$ $\mathrm{ha}^{-1}$ and $\mathrm{P}$ at $50 \mathrm{~kg} \mathrm{ha}^{-1}$ in the first of the two seasons of each year (Source: Bashir Jama, unpublished data). 
biomass). Responses of maize to $\mathrm{P}$ are known to be significant in this area even at rates as low as $10 \mathrm{~kg} \mathrm{P} \mathrm{ha}^{-1}$ (Jama et al. 1997). This is not sufficient to produce the high maize yield associated with the application of Tithonia.

Although the processes associated with the high grain yields with Tithonia are not all fully understood, it could be partitioned into the direct effects of nutrients added and other indirect effects that enhance crop performance. This is demonstrated by the maize grain yield (Fig. 2) of a trial with Tithonia green foliage as a source of $\mathrm{N}$ and $\mathrm{K}$ for maize compared with inorganic fertilizers. Phosphorus was supplied to both $\mathrm{N}$ sources in this trial conducted at a site deficient in all the three major nutrients. Nitrogen and potassium were applied at the rate of $60 \mathrm{~kg} \mathrm{ha}^{-1}$ and $\mathrm{P}$ at $50 \mathrm{~kg} \mathrm{ha}^{-1}$ in the first of the two seasons of each year.

As shown in Fig. 2, the application of urea alone produced maize grain yield of only $0.5 \mathrm{tha}^{-1}$ but it produced about three times that yield (1.5 t $\mathrm{ha}^{-1}$ ) with the addition of $\mathrm{P}$. The addition of $\mathrm{K}$ further increased maize yield from 1.5 to $4.2 \mathrm{t} \mathrm{ha}^{-1}$ (an increase of $180 \%$ ). Similar maize yields (4.5 t $\mathrm{ha}^{-1}$ ) were obtained with Tithonia $+\mathrm{P}$ alone (no added $\mathrm{N}$ and $\mathrm{K}$ ), suggesting that Tithonia could adequately meet both the $\mathrm{N}$ and $\mathrm{K}$ needs of the crop. Compared with $\mathrm{N}+\mathrm{P}+\mathrm{K}$ mineral fertilizer, Tithonia $+\mathrm{P}$ increased maize yield by $0.3 \mathrm{t} \mathrm{ha}^{-1}$ (an increase of $7 \%$ ) and by $0.7 \mathrm{t} \mathrm{ha}^{-1}$ (an increase of $14 \%$ ) with Tithonia $+\mathrm{P}+\mathrm{K}$. These increases are what we refer to as the 'other' benefits of Tithonia beyond the direct supply of $\mathrm{N}, \mathrm{P}$ and $\mathrm{K}$.

Assuming $\mathrm{K}$ deficiency was overcame with the addition of $60 \mathrm{~kg} \mathrm{~K} \mathrm{ha}{ }^{-1}$, the 'other' benefits associated with the application could probably be due to: (1) the provision of micronutrients that may be limiting in the soil, (2) reduction of the soil P-fixing capacity and, therefore, increased $\mathrm{P}$ availability (Nziguheba et al. 1997), (3) release of nutrients from Tithonia is better synchronized with crop demand and, (4) transforming unavailable mineral $\mathrm{P}$ into available forms. No data are available so far on either micronutrient deficiencies of the soils or the ability of Tithonia biomass to overcome it.

Besides the supply of nutrients, organic inputs may also enhance PR solubility. Direct enhancement of Minjingu PR solubility was demonstrated by Ikerra et al. (1994) with compost- and manureamended soil in Tanzania. Such an effect would, indeed, be desirable for low soluble Busumbu PR.

With respect to the agronomic performance of Busumbu PR, Smithson et al. (2003) examined its agronomic effects on maize yield (Table I) compared to MPR, TSP and the blend of BR with TSP (90:10 by weight) at 26 P-deficient on-farm sites in western Kenya. Notwithstanding the high variability in maize yields, there was a significant response to added $\mathrm{P}$ as BPR ( $p=0.001$, average increase $=1.32 \mathrm{t} \mathrm{ha}^{-1}$ ). Triple superphosphate and MPR were not significantly different, but both were significantly different from BPR. The BPR:TSP blend was significantly different from no-P control, but was not different from BPR alone. Though unexpected, mixed results with Busumbu blends are a common observation.

TABLE I

Mean maize grain yields for various $P$ treatments in western Kenya during the 2000 long rains season at 26 farms.

\begin{tabular}{l|c|c|c}
\hline \multirow{2}{*}{\multicolumn{1}{c|}{ Treatment }} & \multicolumn{3}{|c}{ Maize grain yield $\left(\mathrm{t} \mathrm{ha}^{-1}\right)$} \\
\cline { 2 - 4 } & Mean & Min & Max \\
\hline Control (No P) & 2.68 & 0.03 & 6.22 \\
\hline MPR & 5.18 & 0.62 & 7.69 \\
\hline BPR & 4.00 & 0.82 & 7.66 \\
\hline BPR:TSP (90:10) & 4.11 & 1.14 & 6.12 \\
\hline TSP & 5.83 & 2.42 & 7.72 \\
\hline LSD (0.05) & 0.85 & & \\
\hline
\end{tabular}

\section{ECONOMICS OF PHOSPHATE ROCK USE}

The choice between soluble $\mathrm{P}$ fertilizers and PR as a source of $\mathrm{P}$ for crops depends on relative agronomic effectiveness (RAE) and cost. Minjingu PR is the only deposit in eastern Africa with sufficient quantity and reactivity with potential for direct application. Although far from western Kenya ( $820 \mathrm{~km}$ away), the use of Minjingu PR is likely 
to be more economical than TSP in western Kenya. The estimated retail price at Maseno in western Kenya in December 1996 ranged from US\$ 1.3 to $1.8 \mathrm{~kg}^{-1} \mathrm{P}$ compared with about $2.36 \mathrm{US} \$ \mathrm{~kg}^{-1} \mathrm{P}$ of TSP (Buresh et al. 1997). Minjingu PR on a unit $\mathrm{P}$ basis was, therefore, 55 to $76 \%$ of the cost of TSP. This estimate should, however, be interpreted with caution as it was based on limited amount of PR acquired for on-farm research by farmers in a pilot project. It could become even cheaper if the PR was mined and delivered to western Kenya on a large scale.

The economics works out favorable for Minjingu PR with its estimated 55 to $76 \%$ relative cost compared with TSP and approximately 70 to $75 \%$ RAE on acid soils in western Kenya. The onetime large application of $250 \mathrm{~kg} \mathrm{ha}^{-1}$ is perceived as a corrective measure for severely P-deficient soils as opposed to a gradual build-up of phosphorus capital through annual applications of small amounts. However, logistic costs, credit schemes and soil properties will be the main factors to determine source and rate to use. So far, there is limited information on the economic benefits of MPR application under farmers' conditions. For TSP, preliminary assessments indicate that its high cost makes economic returns to either land or labor unattractive at present (Bashir Jama, unpublished data).

\section{DISSEMINATION TO FARMERS}

Based on the encouraging agronomic results and costs of Minjingu PR in western Kenya, extension activities have been focused on training farmers to adapt and adopt the integrated technology of Minjingu PR application and organic sources of nutrient. This combination was effective in sites with multiple nutrient deficiencies as the organics primarily overcame $\mathrm{N}$ and $\mathrm{K}$ deficiencies while the PR met the P needs. Because of their low tissue $\mathrm{P}$ concentration, the organics cannot meet the $\mathrm{P}$ requirements of the crops unless applied at high rates, which is unfeasible and uneconomical.

The major organic sources of nutrients avail- able to farmers were: (1) Tithonia leaf biomass from hedges on farms and (2) short-duration improved fallows with fast-growing species such as Sesbania sesban, Crotolaria grahamiana and Tephrosia vogelii. Tithonia diversifolia is targeted mainly for biomass transfer while the other woody perennials are for improved fallows. These species are relay-cropped with maize 4 to 5 weeks after maize is sown. Relay cropping minimizes negative effects of the woody perennials on crops while allowing the woody perennials to benefit from fertilizer and weeding provided to the crops. The practice also permits the growth of the woody perennials to be extended for two instead of one season. When the crop is harvested at the end of the first season (July-August), the woody perennials are left to grow during the second season until they are cut in February-March and the cropping cycle repeated.

Once the woody perennials are cut, wood is removed and the leaf and small twigs are left on the field and incorporated into the soil during land preparation. Such a fallow can provide 90 to $120 \mathrm{~kg} \mathrm{~N} \mathrm{ha}^{-1}$ depending on rainfall during the fallow period. The source of this $\mathrm{N}$ could be $\mathrm{N}$ found accumulating in the subsoil of the soils of the study area (Hartemink et al. 1996), $\mathrm{N}_{2}$ biologically fixed from the atmosphere and $\mathrm{N}$ mineralized from the soil organic matter. The levels of nutrients provided through the foliage of the woody perennials in improved fallow systems is usually sufficient to produce 3 to 4 tonnes of maize per hectare under farmers' management conditions (Fig. 3). In this sample case of 83 farmers, the yields increased considerably more where farmers supplemented the fallows with $\mathrm{P}$ application, even with amounts as small as $20-30 \mathrm{~kg}$ as demonstrated in Fig. 3. Inorganic nitrogen inputs would, however, be required for higher yields and/or if the fallow biomass is used instead for livestock feed. With Minjingu PR alone, maize yield remained low and was similar to farmers' own practice with manure applications because of $\mathrm{N}$ limitations.

Inorganic fertilizers or intercropping with nitrogen fixing species will also be required to sus- 


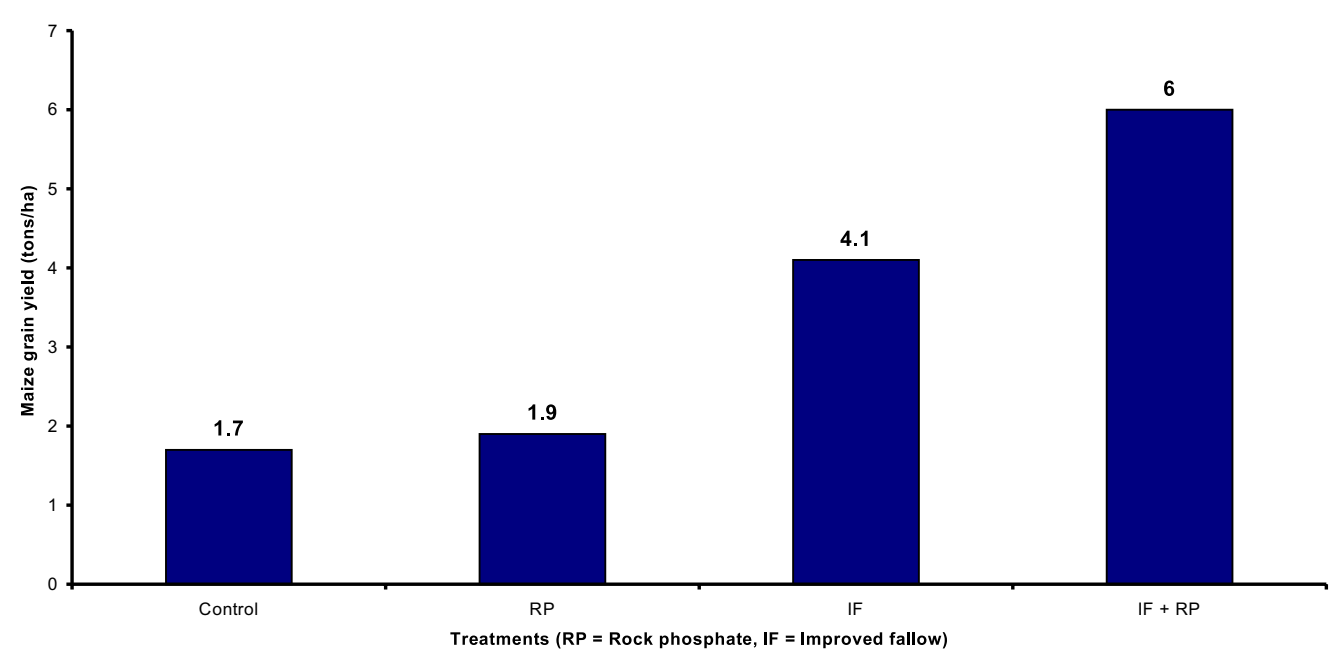

Fig. 3 - Effect of improved fallows and Minjingu phosphate rock on maize grain yield under a case study of 83 farmers in western Kenya (Source: Bashir Jama, unpublished data).

tain Tithonia biomass production since Tithonia is not a legume that can biologically fix atmospheric $\mathrm{N}_{2}$. To determine the sustainability of nutrient supply through Tithonia biomass transfer, one has to consider the possibility that Tithonia planted on the boundaries of the farms and contour bands could act as a trap for nutrients moving down the slope with water and soil or intercropping with $\mathrm{N}$-fixing species. This would minimize the need for external inputs to sustain biomass production of Tithonia, which would also cycle back to the farm nutrients that would otherwise have been lost. What is required, therefore, is an understanding of nutrient acquisition mechanism by Tithonia and redistribution of nutrients within the landscape through transfer of Tithonia biomass. Long-term studies or farm nutrient budgets may also help determine the sustainability of Tithonia-use systems.

Thousands of farmers are currently testing and adapting improved fallows, many with integration of Minjingu PR where it is available, TSP and other minerals fertilizers, and with Tithonia and improved fallows. Farmers are extremely pleased with the results, as their crop yields have increased many folds as is evident from Fig. 3. Farmers are also testing these technologies on many crops - maize, beans and vegetables such as kale (Brassica oleraceae) and tomato. Tithonia biomass transfer can be labor intensive but its use is attractive to farmers on such crops as kale that are higher-valued than maize (ICRAF 1998).

\section{CONCLUSIONS}

Phosphorus deficiency limits crop productions in several areas of East Africa, notably in the densely populated highlands of western Kenya. In this area, options to replenish soil $\mathrm{P}$ include the use of Minjingu PR from northern Tanzania. This sedimentary PR with 70 to $75 \%$ RAE is suitable for direct application in the $\mathrm{P}$ deficient acidic soils of western Kenya and is estimated to cost about 24 to $45 \%$ less than P from TSP. This makes the use of this PR a near substitute for commercially available soluble $\mathrm{P}$ fertilizers. In addition to Minjingu, Busumbu PR from eastern Uganda is also under evaluation although this PR is not as soluble as Minjingu PR and does, therefore, require some modification, e.g. blending with soluble $\mathrm{P}$ sources.

The soils in many areas of western Kenya have multiple nutrient deficiencies, which need to be corrected in order to obtain meaningful crop 
yields. The best strategy to correct these deficiencies is the integration of organic sources of nutrients with inorganic $\mathrm{P}$ sources (PR or soluble $\mathrm{P}$ fertilizers). Promising organic sources of nutrients are transfer of Tithonia green foliage from hedges on farm boundaries to cropped fields and improved fallows with fast-growing woody perennial and shrubs such as Sesbania sesban, Crotalaria grahamiana and Tephrosia vogelii. These and many other organics can provide some $\mathrm{P}$ to crops but not at adequate levels and at economic rates of application because of their low tissue $\mathrm{P}$ concentration. These added organic materials can, however, provide sufficient $\mathrm{N}$ and $\mathrm{K}$ for moderate crop yields (for example, 3 to $4 \mathrm{t} \mathrm{ha}^{-1}$ maize grain yields) because of their higher $\mathrm{N}$ and $\mathrm{K}$ concentrations compared with $\mathrm{P}$.

Farmers in western Kenya are excited about this approach of integrating organic and inorganic fertilizers to improve and manage the fertility of their soils. One of the reasons for the excitement is that they don't have to purchase the organics they can obtain or grow them on their farms. As a consequence, a large number of farmers are now using and testing the integrated organic and inorganic fertilizer package on several crops - such as maize, maize and beans intercropped and vegetables. They have also put in place soil conservation measures. What is required to make this package more attractive and sustainable is a supportive policy environment that includes better rural infrastructure. This is necessary for the supply of farm inputs like Minjingu PR and mineral fertilizers at reasonable costs and better marketing of farm produce.

\section{RESUMO}

A deficiência de fósforo afeta em torno de $80 \%$ dos solos ácidos do Quênia ocidental, mas o uso de fertilizantes é limitado devido aos preços altos. Este artigo explora o potencial das rochas fosfáticas locais (PR) como regenerador da fertilidade dos solos dentro do contexto de uma abordagem de gestão integrada. Uma rocha fosfática promissora é a Minjingu PR (MPR, Tanzânia), um depósito sedimentar/biogênico que contém por volta de $13 \%$ total P e 3\% citrato neutro de amônia (NAC) P solúvel. Testes em fazendas agrícolas com solos deficientes em P no Quênia ocidental demonstram que a MPR é tão efetiva quanto o superfosfato triplo (TSP, 20\% P) na mesma proporção de $\mathrm{P}$. Os benefícios são mais pronunciados com a integração das tecnologias agroflorestais que melhoram a fertilidade do solo. Da mesma forma que o Minjingu PR, Busumbu PR de Uganda (BPR) é outra fonte potencial de P. É típica do abundante, porém não-reativo complexo ígneo PRs do leste, centro e sul da África. A performance agronômica de BPR é inferior ainda que tenha custo mais baixo e localização próxima às áreas deficientes de P no Quênia ocidental, tornandose mais atrativo em algumas situações. As implicações políticas dessas descobertas são discutidas mais adiante neste artigo.

Palavras-chave: fertilizantes, milho, mellhorando terras em pousio, Tithonia, África Oriental.

\section{REFERENCES}

BALDOCK JW. 1969. Geochemical dispersion of copper and other elements at the Bukusu carbonatite complex, Uganda. T I Min Metall B 78: B12-B28.

BROMFIELD AR, HANCOCK IR AND DEBENHAM DF. 1981. Effects of ground $P R$ and elemental $S$ on yield and $\mathrm{P}$ uptake of maize in western Kenya. Exp Agric 17: $383-387$.

Buresh RJ, Smithson PC AND Hellums DT. 1997. Building soil phosphorus capital in Africa. In: BuRESH RJ, SANCHEZ PA AND CALHOUN F (Eds), Replenishing soil fertility in Africa. SSSA Special Publication No. 51, Soil Science Society of America, Madison, Wisconsin, USA, p. 111-149.

Chien SH, Sompongse D, Henao J and Hellums DT. 1987. Greenhouse evaluation of phosphorus availability from compacted phosphate rocks with urea and triple superphosphate. Fert Res 14: 245256.

Chien SH, Menon RG and Billingham KS. 1996. Phosphorus availability from phosphate rock as enhanced by water-soluble phosphorus. Soil Sci Soc Am J 60: 1173-1177.

DAVIES KA. 1947. The phosphate deposits of the Eastern province, Uganda. Econ Geol 42: 137-146. 
HARTEMINK AE, BURESH RJ, JAMA BA AND JANSSEN BH. 1996. Soil nitrate and water dynamics in sesbania fallows, weed fallows and maize. Soil Sci Soc Am J 60: 568-574.

ICRAF. 1998. Annual report for 1997. International Centre for Research in Agroforestry. Nairobi, Kenya.

IKERRA TWD, MNKENI PNS AND SINGH BR. 1994. Effects of added compost and farmyard manure on $P$ release from Minjingu PR and its uptake by maize. Norw J Agric Sci 8: 13-23.

JAma B, Swinkels RA AND BuResh RJ. 1997. Agronomic and economic evaluation of organic and inorganic phosphorus in western Kenya. Agron J 89: 597-604.

Jama BA, Palm CA, Buresh RJ, Niang AI, GAChengo C, Nziguheba G and Amadalo B. 2000. Tithonia diversifolia as a green manure for soil fertility improvement in western Kenya: a review. Agroforestry Systems 49: 201-221.

Nyasimi M, Niang A, Amadalo B And Obonyo E. 1997. Using the wild sunflower, tithonia, in Kenya. ICRAF, KARI and KEFRI, Nairobi, Kenya, 12 p. (English and Swahili versions).

NZiguheba G, PALM CA, Buresh RJ ANd SMithSON PC. 1997. Soil phosphorus fractions and adsorption as affected by organic and inorganic sources. Plant Soil 198: 159-168.

PALM CA, Myers RJK ANd NANdWA SM. 1997. Combined use of inorganic and organic nutrient sources for soil fertility maintenance and replenishment. In: Buresh RJ, SANCHEZ PA AND CALHOUN F (Eds), Replenishing soil fertility in Africa. SSSA Spec Publ 5, Soil Sci Soc Am, Madison, Wisconsin, USA, p. 193-217.

RAJAN SSS, WATKINSON JH AND SINCLAIR AG. 1996. Phosphate rocks for direct application to soils. Adv Agr 57: 77-159.

SANCHEZ PA. 1976. Properties and management of soils in the tropics. J Wiley \& Sons, New York, USA.

Sanchez PA, Shepherd KD, Soule MJ, Place FM, Buresh RJ, IZAC AN, MOKWUNye AU, KWESIGA FR, NDIRITU CG AND WOOMER PL. 1997. In: BuRESH RJ, SANCHEZ PA AND CALHOUN F (Eds), Replenishing soil fertility in Africa. SSSA Spec Publ 51, Soil Sci Soc Am, Madison, Wisconsin, USA, p. 1-46.
SHEPHERD KD AND Soule MJ. 1998. Assessment of the economic and ecological impacts of agroforestry and other soil management options on western Kenya farms using a dynamic simulation model. Agric Ecosys Environ 71: 131-145.

Smithson P, Jama B, Delve R, Van Straaten P AND BURESH R. 2003. East African phosphate resources and their agronomic performance. In: RAJAN SSS AND CHIEN SH (Eds), Direct application of phosphate rock and related appropriate technology - latest developments and practical experiences: Proceedings of an international meeting, International Center for Soil Fertility and Agricultural Development (IFDC), Muscle Shoals, Alabama, USA, Spec Publ IFDC-SP 37: 123-133.

SWINKEls RA, FrAnZEl S, SHEPHERD KD, OHLSSON E AND NDUfA JK. 1997. The economics of short rotation improved fallows: evidence from areas of high population density in western Kenya. Agric Syst 55: 99-121.

VAN KAUWENBERGH SJ. 1991. Overview of phosphate deposits in East and Southeast Africa. Fert Res 30: 127-150.

VAn StraAten P. 2002. Rocks for crops: Agrominerals of sub-Saharan Africa. ICRAF, Nairobi, Kenya, $338 \mathrm{p}$.

van Straaten P And Fernandes TRC. 1995. Agrogeology in Eastern and Southern Africa: a survey with particular reference to developments in phosphate utilization in Zimbabwe. In: BLENKINSOP TG AND Tromp PL (Eds), Sub-Saharan Economic Geology. Geol Soc Zimbabwe Spec Publ 3, Balkema Publ, Netherlands, p. 103-118.

WOOMER PL, OKALEBo JR AND SANCHEZ PA. 1997. Phosphorus replenishment in western Kenya: from field experiments to an operational strategy. African Crop Sci J 3: 559-570. 